\title{
Metal ions as regulators of the conformation and function of the tumour suppressor protein p53: implications for carcinogenesis
}

\author{
Catherine Méplan ${ }^{1}$, Gerald Verhaegh ${ }^{1 *}$, Marie-Jeanne Richard ${ }^{2}$ and Pierre Hainaut ${ }^{1} \dagger$ \\ ${ }_{1}^{1}$ International Agency for Research on Cancer, 150 Cours Albert Thomas, F69372 Lyon Cedex 08, France \\ ${ }^{2}$ Laboratoire de Biochimie C, Centre Hospitalier et Universitaire Albert Michalon, F38043 Grenoble Cedex 9, France
}

\begin{abstract}
The $\mathrm{p} 53$ protein is a multi-function nuclear factor that is activated in response to multiple forms of stress and controls the proliferation, survival, DNA repair and differentiation of cells exposed to potentially genotoxic DNA damage. Loss of p53 function by mutation is a frequent event in human cancer, and is thought to result in the capacity of cells to acquire and accumulate oncogenic mutations during the progression of neoplasia. The p53 protein is a metal-binding transcription factor that is inactivated by metal chelation and by oxidation in vitro. In intact cells, p53 protein activity is crucially dependent on the availability of $\mathrm{Zn}$ ions and is impaired by exposure to $\mathrm{Cd}$, a metal which readily substitutes for $\mathrm{Zn}$ in a number of transcription factors. Inactivation by $\mathrm{Cd}$ suppresses the p53-dependent responses to DNA damage. Overall, these findings indicate that regulation by metals plays an important role in the control of $\mathrm{p} 53$, and that perturbation of this control may explain the carcinogenic potential of several metal compounds.
\end{abstract}

\section{Résumé}

\begin{abstract}
La protéine p53 est un facteur nucléaire multi-fonctionnel qui est activé en réponse à de multiples formes de stress et qui contrôle la prolifération, la survie, la réparation de l'ADN et la différenciation de cellules exposées à des agents génotoxiques. La perte de la fonction de p53 par mutation est un évènement fréquent dans les cancers chez l'homme, et l'on considère que cette inactivation a pour conséquence de rendre la cellule susceptible d'accumuler rapidement des mutations oncogéniques au cours de la progression du cancer. La protéine p53 est un facteur de transcription qui lie les métaux et qui peut être inactivée in vitro par chélation des métaux ainsi que par oxydation. Dans des cellules en culture, l'activité biologique de la p53 dépend de la biodisponibilité en $\mathrm{Zn}$, et est altérée par l'exposition des cellules au $\mathrm{Cd}$, un métal qui se substitue facilement au Zn dans nombre de facteurs de transcription Zn-dépendants. L'inactivation de p53 par le $\mathrm{Cd}$ inhibe les réponses p53-dépendantes suite à la formation de lésions de l'ADN. Globalement, ces données suggèrent que la régulation par les métaux joue un rôle important dans le contrôle de la p53, et que des perturbations de ce contrôle pourraient contribuer à expliquer le potentiel carcinogénique de certains composés métalliques.
\end{abstract}

Tumour suppresser protein p53: Zinc: Cadmium: Carcinogenesis

The p53 tumour suppressor gene encodes a $53 \mathrm{kDa}$ nuclear phosphoprotein present in a latent form in most cells and tissues. The protein becomes activated in response to multiple forms of physical and chemical stress, including DNAdamaging agents of several kinds, oxidants, hypoxia, drugs that deplete ribonucleotide pools or microtubules, and proinflammatory cytokines such as tumour necrosis factor- $\alpha$ (Fig. 1). Once activated, p53 acts as a multi-functional transcription factor to control the expression of several sets of genes collectively termed p53-induced-genes. The p53 protein also binds to several proteins of the replicationtranscription-repair processes. Together, these biological activities result in a coordinated control of essential cellular processes such as cell-cycle regulation, apoptosis, DNA repair and differentiation (Agarwal et al. 1998; Hainaut \& Hollstein, 1999). The p53 protein thus acts as a regulator of

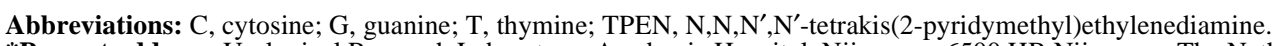

*Present address: Urological Research Laboratory, Academic Hospital, Nijmegen, 6500 HB Nijmegen, The Netherlands.

†Corresponding author: Dr Pierre Hainaut, fax +33 4727383 21, email Hainaut@iarc.fr 

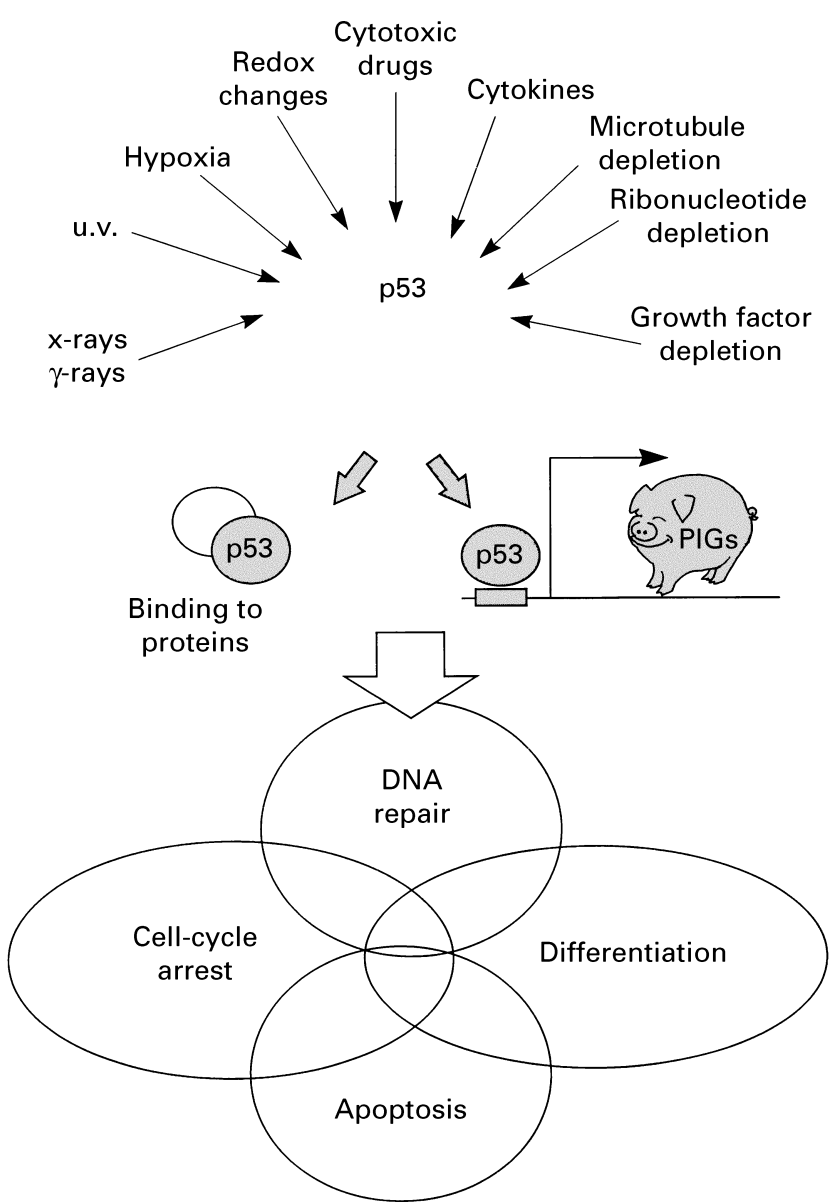

Fig. 1. A schematic view of the p53 pathway. p53 acts as a sensor of multiple forms of stress. After activation by stress, p53 binds DNA as a sequence-specific transcription factor to activate target genes collectively termed p53-inducible genes (PIGs). The protein also forms complexes with other cellular components. These interactions allow p53 to control a complex network of cellular responses, including cell-cycle arrest, apoptosis, DNA repair and differentiation.

the proliferation and genomic stability of cells exposed to forms of stress that have the potential to create oncogenic DNA damage. Mice rendered deficient for the p53 gene by homologous recombination show a spectacular increase in the rate of spontaneous tumours at multiple organ sites. This anti-tumour function has earned p53 the nickname 'guardian of the genome' (Lane, 1992; Levine, 1997).

\section{Mutations of p53 and human cancer}

Point missense mutations in the p53 gene are the most frequent genetic event identified to date in human cancer. Since the identification of the first mutation in 1989, more than 10000 mutations associated with cancer have been described. These mutations are compiled in a database maintained at the International Agency for Research on Cancer (http://www.iarc.fr/p53/homepage.htm; also, see Hainaut et al. 1998). Mutations in the p53 gene are found in most common forms of invasive or advanced cancers, with frequencies varying from $80 \%$ in some cancers of the upper digestive and respiratory tracts, to $1-5 \%$ in malignant melanoma and testicular cancers. In cancers, such as colon and breast, mutation of one allele of p53 is thought to occur at a relatively late stage in the sequence of genetic events leading to cancer, and is generally associated with the loss of the other allele. However, in other common malignancies, such as lung cancers and head-and-neck cancers of smokers, p53 mutation is sometimes detectable in pre-cancerous tissues or in early lesions, and the wild-type allele is often retained. This observation has led to the notion that some mutations of p53 could confer to the protein a dominant-negative phenotype. Thus, inactivation of p53 in cancer does systematically obey the classical 'two-hits' hypothesis for inactivation of tumour suppressor gene, as defined by Knudson (1971) in the case of the retinoblastoma susceptibility gene.

The p53 gene contains eleven exons, the first being noncoding. About $90 \%$ of p53 mutations described to date fall within exons 4-9 that encode the specific DNA-binding domain of the protein. One-third of these mutations cluster at six 'hotspot' codons that are mutated in almost every form of cancer, including codons 175, 245, 248, 249, 273 and 282. However, the distribution, nature and relative frequency of mutations show great variability from one tumour type to another. This variability has generated a lot of interest in trying to define tumour-specific mutation patterns that allow hypotheses to be generated on the aetiology or pathogenesis of human cancers (Greenblatt et al. 1994; Hernandez \& Hainaut, 1998). For example, in lung cancers of smokers, transversions from guanine $(\mathrm{G})$ to thymine $(\mathrm{T})$ occur frequently at base positions that are experimentally known as sites of formation of DNA adducts by metabolites of benzo(a)pyrene, one of the major tobacco carcinogens. Non-melanoma skin cancers often contain tandem transitions from cytosine (C) to T (CC to TT), a typical molecular signature of mutagenesis by u.v. Mutations induced by the dietary mutagen aflatoxin B1 have been identified in hepatocellular carcinomas arising in areas of the world where this mycotoxin is a common food contaminant. Alcohol intake, in combination with tobacco, has been suggested as a risk factor in the formation of p53 mutations in cancers of the head and neck and of the upper digestive tract. However, there is good molecular evidence that many p53 mutations may not have an external cause and result from endogenous mutational mechanisms. About $25 \%$ of all mutations are $\mathrm{C}$ to $\mathrm{T}$ transitions at $\mathrm{CpG}$ dinucleotides, a type of mutation that occurs by spontaneous deamination of methylated C (Hainaut \& Hollstein, 1999).

\section{The p53 signalling pathways}

The nature of the molecular signals that activate p53 functions is now beginning to emerge. DNA-strand break damage is an important common denominator to many p53 activators. This form of damage activates kinases such as the double-stranded DNA-dependent kinase and ATM (the product of the gene responsible for ataxia-telangiectasia, a rare autosomal disorder characterized by, among other traits, cerebellar ataxia and hypersensitivity to ionizing radiation). Both these kinases phosphorylate p53 in the $\mathrm{N}$-terminal region (containing the transactivation domain) and disrupt the association of p53 with the protein $\mathrm{mdm} 2$ (Shieh et al. 1997; Siliciano et al. 1997; Waterman et al. 1998; Woo et al. 1998). By binding to the N-terminus, 
mdm2 conceals the transactivation domain of p53 and targets p53 for rapid degradation by the proteasome (Oliner et al. 1993; Haupt et al. 1997; Kubbutat et al. 1997). Escape from mdm 2 binding allows p53 to accumulate and to interact with other cellular factors, including acetyl transferases of the CREB-binding protein/p300 family. These proteins mediate the acetylation of specific lysine residues in the C-terminus of $\mathrm{p} 53$, leading to conformational modifications of the protein that activate the capacity to bind specifically to defined DNA sequences located in the promoter regions of target genes (Gu \& Roeder, 1997). An additional step in the regulation of DNA binding includes the reduction of several important cysteines located within the DNA-binding domain. The dual function, redox-repair enzyme Ref-1 may be involved in this process (Jayaraman et al. 1997).

Activation of p53 may also occur in response to other signals. For example, hypoxia induces the expression of the hypoxia-inducible factor Hif-1, which binds p53 and stimulates its activity (Graeber et al. 1996; An et al. 1998). How p53 'senses' other forms of stress is still not clearly understood.

The p53-induced genes represent a rapidly-growing group of genes that belong to several distinct families. One family includes genes that regulate the progression of the cell cycle in phases $\mathrm{G} 1$ (e.g. the p $21^{\text {waf- }} 1$ cyclin kinase inhibitor) and G2 (e.g. the signal transduction protein 14-3-3 $\sigma$ ). Another important family includes regulators of cell death (such as the death receptors Fas/APO1/CD95 and Killer/DR5, and Bax-1, a regulator of mitochondrial membrane permeability; Hainaut \& Hollstein, 1999). Recently, a number of new p53-induced genes have been identified in cells undergoing p53-dependent apoptosis; they include several genes, the products of which are potentially involved in the production or scavenging of reactive oxygen species (Polyak et al. 1997). This finding raises the possibility that reactive oxygen species may act as 'second messengers' in some of the signalling pathways that control cell proliferation and survival.

Proteins bound by activated p53 include the replication protein-A, the basal transcription factor TATA-box-binding protein and helicases involved in DNA repair such as ERCC2 and ERCC3. The nature, extent and duration of the p53-dependent response are dependent on the intensity of the p53-inducing stress and of the type of cell and tissue considered. In some cell types induction of p53 results in permanent or transient cell-cycle arrest, which may help in the completion of extensive DNA repair. In other cells induction of p53 results in apoptosis, which may facilitate the elimination of cells that contain genes damaged beyond repair. Both these mechanisms effectively contribute to the prevention of the replication of cells exposed to genotoxic factors, thereby limiting the risk of formation and propagation of genetic abnormalities leading to cancer (Levine, 1997).

\section{Role of metals in the control of p53 conformation and activity}

Transition metals play an important role in maintaining the tertiary structure of the DNA-binding domain of $\mathrm{p} 53$. This domain is made of a complex array of two beta-sheets that support large loop-helix structures directly involved in contacting target DNA. These loops are bridged together by the tetrahedral coordination of a divalent $\mathrm{Zn}$ on three cysteines (residues 176, 238 and 242) and one histidine (residue 179; Fig. 2; Cho et al. 1994). Although reminiscent of the classical 'zinc finger' of many transcription factors, this structure is unique to p53 and shows a high degree of flexibility. In vitro, exposure of recombinant p53 to metal chelators disrupts the structure of the DNA-binding domain and abolishes the capacity of p53 to bind specifically to DNA. Metal chelation results in the formation of disulphidelinked p53 complexes, suggesting that removal of the $\mathrm{Zn}$ favours oxidation of cysteines within the DNA-binding domain. In addition, thiol antioxidants stabilize the structure of the DNA-binding domain and increase the binding of p53 to DNA. These biochemical features have led to the hypothesis that p53 may be regulated by metal ions and by oxidoreduction in vivo (Hainaut \& Milner, 1993a,b).

To further analyse the role of $\mathrm{Zn}$ in the control of p53 activity, we have exposed cultured cells expressing wildtype p53 to the cell-permeant metal chelator $\mathrm{N}, \mathrm{N}, \mathrm{N}^{\prime}, \mathrm{N}^{\prime}$ tetrakis(2-pyridymethyl)ethylenediamine (TPEN). Whereas DNA-damaging agents induced p53 to accumulate and stimulate DNA binding, TPEN induced p53 to accumulate in a form unable to bind DNA. This effect was abolished when cells were exposed to TPEN plus $\mathrm{Zn}$, indicating that neutralization of the chelator inactivated its inhibitory effect (Fig. 3 (A and B); Verhaegh et al. 1998). Using conformation-specific antibodies, we have shown that the inhibitory effect of TPEN correlated with a change in p53 protein conformation, similar to that observed in recombinant p53 exposed to metal chelators in vitro. Together,

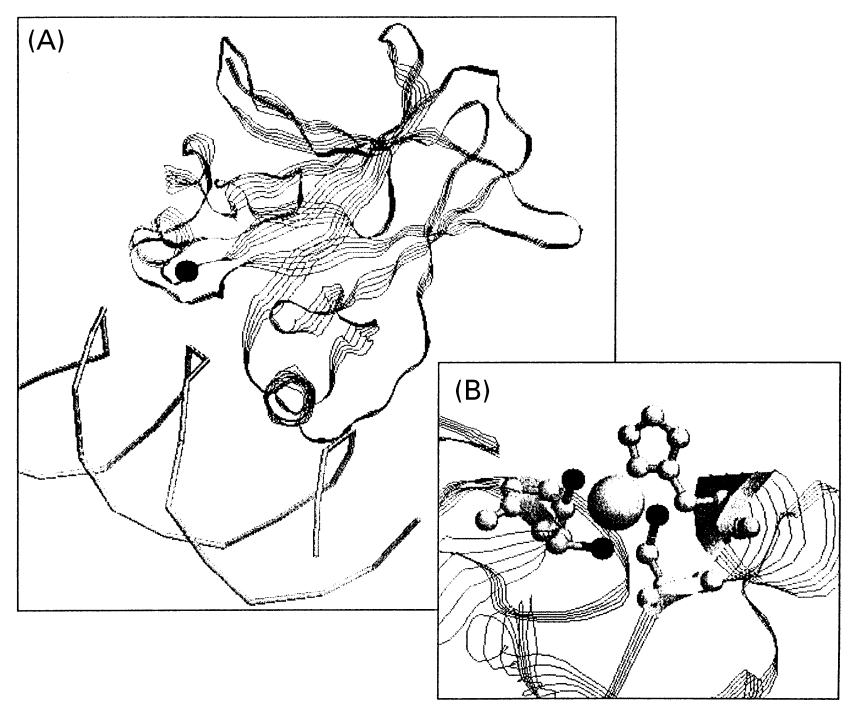

Fig. 2. Structure of the metal-binding site in p53. (A) The crystal structure of the DNA-binding domain of p53 (residues 102-296) in complex with DNA is shown. DNA is represented by its phosphate backbone. ( ), The zinc atom, that bridges two large loops at the protein-DNA interface. (B) A close-up view of the metal-binding site, showing the tetrahedral coordination of zinc by three cysteines and one histidine. Crystal structure data are from Cho et al. (1994), with modifications. The structure was visualized using RasMol 2.6 software (Research Collaboratory for Structural Biolnformatics; http://www.rcsb.org). 
(A)

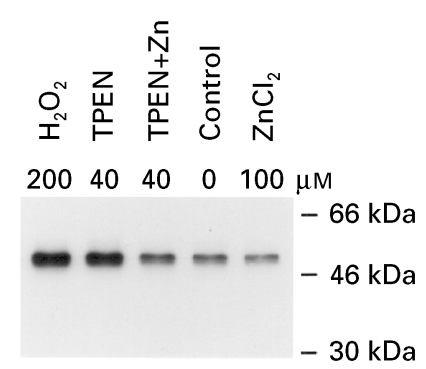

(B)

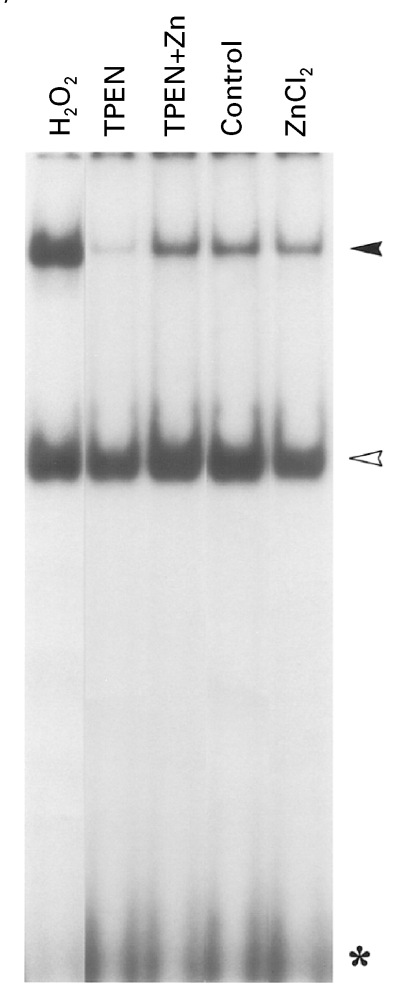

Fig. 3. Inhibition of the p53 protein in intact cells by the metal chelator $\mathrm{N}, \mathrm{N}, \mathrm{N}^{\prime}, \mathrm{N}^{\prime}$-tetrakis(2-pyridymethyl)ethylenediamine (TPEN). The breast cancer cell line MCF7, which expresses wild-type p53, was cultured for $2 \mathrm{~h}$ in the presence of TPEN $(40 \mu \mathrm{M})$, zinc $(100 \mu \mathrm{M})$ or TPEN plus zinc. Hydrogen peroxide, a classical DNA-damaging agent that induces p53, was used as positive control. (A) Western blot analysis of p53 protein levels using the monoclonal antibody DO7, showing p53 protein levels. (B) DNA gel shift assay using a radiolabelled oligonucleotide containing a specific p53 binding site (Funk et al. 1992). Nuclear cell extracts were incubated with the oligonucleotide according to a protocol described elsewhere (Verhaegh et al. 1998) and the radiolabelled DNA was resolved on a non-denaturing gel electrophoresis. ( 4 ) Complexes between p53 and specific DNA. $(\triangleleft)$ A band corresponding to a protein other than p53 that binds DNA in a non-sequence-specific manner. *Free DNA probe (from Verhaegh et al. 1998, with permission).

these findings indicate that chelation of $\mathrm{Zn}$ inactivates p53 in intact cells (Verhaegh et al. 1998).

Removal of TPEN from the culture medium allowed p53 to fold back in the native conformation and to recover DNAbinding activity. Refolding required the presence of $\mathrm{Zn}^{2+}$ in the culture medium, as p53 remained essentially inactive when the culture medium containing TPEN was replaced by a metal-free medium. However, addition of trace amounts of $\mathrm{Zn}$ to this metal-free medium was sufficient to fully restore p53 activity (C Méplan and P Hainaut, unpublished results). As exposure to TPEN induced p53 to accumulate, removal of TPEN resulted in a dramatic increase in DNA-binding activity, with increased transcription of target genes such as p2 $1^{\text {waf- }} 1$ and transient cell-cycle arrest at the G1/S border (Verhaegh et al. 1998).

Additional evidence for a role for metals in the control of p53 was obtained using a class of antioxidants that are wellknown regulators of several redox-dependent transcription factors, the dithiocarbamates. Similar to TPEN, we found that dithiocarbamates inhibited the DNA-binding activity of p53. Measurement of the intracellular concentration of metal ions revealed that inhibition of p53 was correlated with intracellular accumulation of $\mathrm{Cu}$ ions, a well described effect of dithiocarbamates. Blocking $\mathrm{Cu}$ intake with bathocuproine disulphonic acid, a chelator that does not penetrate into the cells, prevented the inhibition of p53 by dithiocarbamates (Verhaegh et al. 1997). These results are in agreement with in vitro data showing that $\mathrm{Cu}$ ions bind to p53 and disrupt its native conformation (Hainaut et al. 1995). Overall, our results provide good experimental evidence that p53 is metallo-regulated in intact cells.

\section{Inhibition of p53 by cadmium, a carcinogenic metal}

The experimental data described previously led us to postulate that several metals may exert carcinogenic effects through their capacity to interact with p53 and to impair its function, thus producing a biological effect comparable with mutation in the p53 gene. To test this hypothesis, we examined the effects of $\mathrm{Cd}$, a metal which is chemically close to $\mathrm{Zn}$ and which is a demonstrated carcinogen in human subjects and animals (International Agency for Cancer Research, 1993). Exposure of cells expressing wildtype p53 to Cd resulted in a dose-dependent inhibition of the DNA-binding and gene transactivation activities of p53, and this inhibition was at least partially reversible on removal of $\mathrm{Cd}$ from the culture medium. Furthermore, $\mathrm{Cd}$ at a relatively low level $(10 \mu \mathrm{M})$ significantly decreased the extent of p53 protein induction after exposure to DNA-damaging agents (Fig. 4). Finally, Cd was shown to abolish the p53dependent cell-cycle arrest in phases G1 and G2 inducted by $\gamma$-irradiation, thus allowing cells to continue to proliferate under genotoxic stress conditions that normally trigger a protective cell-cycle arrest response (Fig. 5). These findings suggest that $\mathrm{Cd}$ disrupts the metal-dependent control of p53 function, a mechanism that may account for some of its so far unexplained carcinogenic effects (C Méplan, K Mann and $P$. Hainaut, unpublished results).

\section{Conclusion: toxicological significance of p53 redox- and metallo-regulation}

Free radicals play important regulatory roles in the signalling pathways upstream and downstream of p53. They participate in $\mathrm{p} 53$ protein induction through their capacity to create DNA-strand break damage. In turn, p53 activates several genes that regulate the production of reactive oxygen 


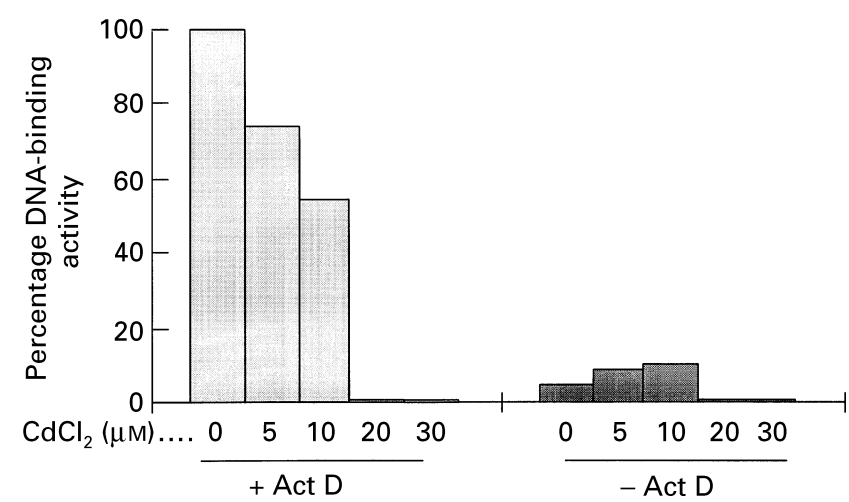

Fig. 4. Inhibition by cadmium of p53 protein induction by actinomycin $D(A c t D)$. MCF7 cells were exposed for $2 \mathrm{~h}$ to cadmium chloride at the indicated concentration, followed or not by exposure for $4 \mathrm{~h}$ to the topoisomerase I ( $E C 5.99 .1 .2)$ inhibitor Act D $(2.5 \mathrm{ng} / \mathrm{ml})$, a classical inducer of DNA-strand breaks that activates p53. Nuclear extracts were then prepared and analysed using the gel-shift assay (Funk et al. 1992). The intensity of the band corresponding to p53DNA complexes was measured by densitometry. Results are expressed as a percentage of the amount of p53-DNA complexes detected in cells exposed to Act $D$ in the absence of cadmium. species. In this context, the intrinsic redox- and metalsensitivity of the $\mathrm{p} 53$ protein may be seen as part of a complex autoregulatory feedback network that modulates the fine-tuning of p53 activity.

The data summarized here have two important potential implications. First, metal ions such as $\mathrm{Zn}$ might play a role as signalling molecules in the control of p53 protein function. Second, disruption of this control by a number of biochemical mechanisms might result in impaired p53 function, and thus contribute to cancer. Mechanisms that can perturb p53 metallo-regulation include exposure to strong thiol oxidants such as NO (Calmels et al. 1997), or to metals that bind reactive thiols and can displace $\mathrm{Zn}$, such as $\mathrm{Cd}$ and $\mathrm{Cu}$. A consequence of this hypothesis is that a number of cellular factors involved in the regulation of intracellular metal fluxes may also act as regulators of p53 activity. These factors include metallothioneins, a class of small, cysteine-rich metal-binding proteins that act as biological metal chelators to protect cells against toxic metal stress and to regulate a number of physiological metaltransfer reactions (Vallee, 1991).

$\mathrm{Cd}$ is a widespread environmental pollutant that is present at high levels in several carcinogenic mixtures, as for example in tobacco smoke. The results presented here suggest that $\mathrm{Cd}$ may act as a co-carcinogen that sensitizes cells to the genotoxic effects of other endogenous or exogenous mutagens (Fig. 6). This model may also hold for (a) Untreated

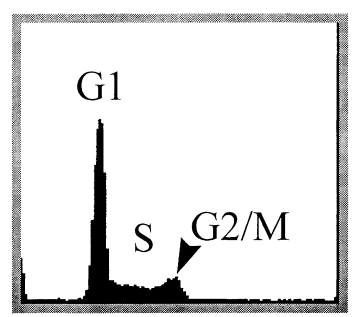

(b) Irradiated

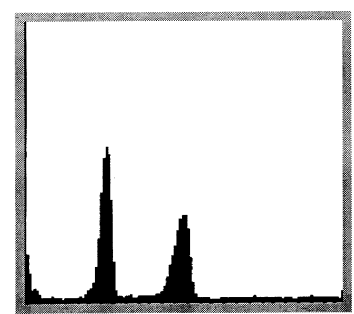

(c) $10 \mu \mathrm{M} \mathrm{CdCl} 2$

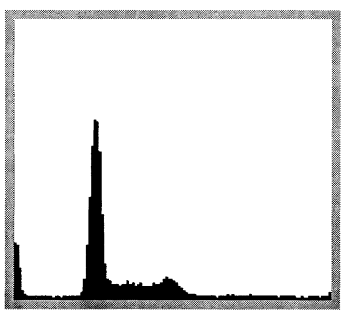

(d) Irradiated $+10 \mu \mathrm{M} \mathrm{CdCl}_{2}$

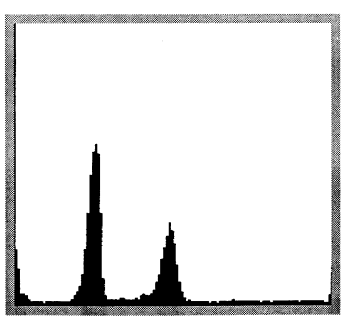

(e) $30 \mu \mathrm{M} \mathrm{CdCl} 2$

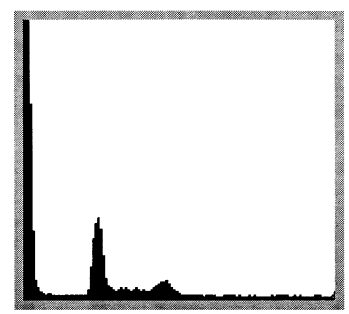

(f) Irradiated $+30 \mu \mathrm{M} \mathrm{CdCl} 2$

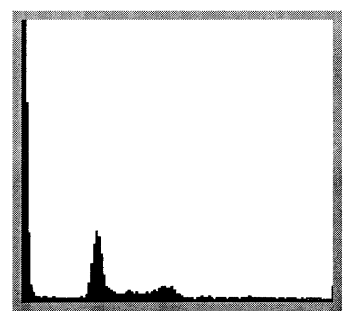

Fig. 5. Impaired cell-cycle arrest after $\gamma$-irradiation in cells exposed to cadmium. Control MCF7 cells or cells cultured in the presence of cadmium at 10 or $30-\mu \mathrm{M}$ were $\gamma$-irradiated ( $5 \mathrm{~Gy}$ ) and cell-cycle distribution was analysed $24 \mathrm{~h}$ later by flow cytometry using a FacsCalibur (Becton-Dickinson, San Jose, CA, USA) after labelling with propidium iodide. (a) The cellcycle distribution of untreated cells showing the position of cell-cycle phases G1, S and G2/M. In cells irradiated in the absence of cadmium (b), cell-cycle arrest in $\mathrm{G} 1$ and in $\mathrm{G} 2 / \mathrm{M}$ is detected by the relative accumulation of the cells in the G1 and G2/M peaks, and by the decrease of cells in S-phase. Culture in the presence of cadmium (c,e) reduces the cell-cycle arrest. At $30 \mu \mathrm{M}$-cadmium, irradiated (f) and non-irradiated cells (e) show identical cell-cycle profile, indicating the cadmium has suppressed the cell-cycle arrest induced by irradiation. 


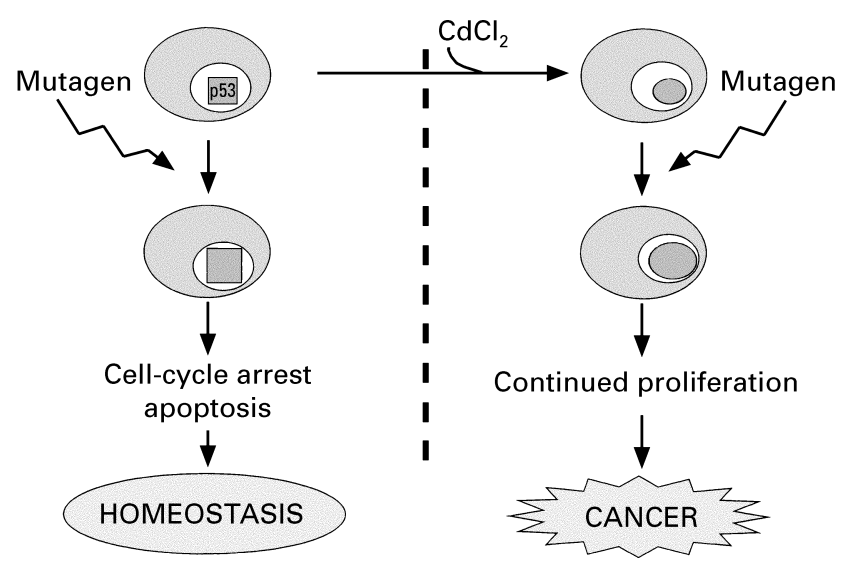

Fig. 6. A model for the role of cadmium in environmental carcinogenesis. The left part of this scheme shows the normal p53dependent cellular responses to mutagens: activation of p53 in the wild-type suppressor form leads to cell-cycle arrest and/or apoptosis, providing protection against genotoxic DNA-damage. In the presence of cadmium (right part of the scheme) p53 conformation is altered, and the protein behaves in a manner which is functionally similar to mutant $\mathrm{p} 53$. The conformation change induced by cadmium prevents cells undergoing normal p53-dependent responses to mutagens, and this continued cell proliferation might allow the expansion of clones of cells which have acquired oncogenic DNAdamage.

a number of other situations where the physiological metal balance is deregulated. For example, in the Long-Evans Cinnamon rat intrahepatic accumulation of $\mathrm{Cu}$ favours the occurrence of a high frequency of liver tumours $(\mathrm{Wu}$ et al. 1994). Rats fed on a low-Zn diet show an increased susceptibility to the formation of oesophageal tumours following the injection of carcinogenic nitrosamines (Fong et al. 1997). In human subjects, $\mathrm{Zn}$ deficiency has been implicated as one of several aetiological factors in the pathogenesis of squamous cell carcinoma of the oesophagus in geographic areas where this type of tumour is frequent, such as central Asia and some regions of China (Wahrendorf et al. 1988). Of course, it has to be considered that changes in metal levels may affect numerous other cellular proteins in addition to p53. Nevertheless, the molecular and cellular findings presented here provide support for further experimental animal studies as well as for epidemiological studies to evaluate the possibility that metals may be important contenders in the control of basic cellular processes such as cell-cycle progression, apoptosis, and regulation of genomic stability.

\section{Acknowledgements}

C. M. is supported by grants of the French Ligue Contre le Cancer (1996-7) and of the Volvic Foundation for Research on Trace Elements (1998-2000).

\section{References}

Agarwal ML, Taylor WR, Chernov MV, Chernova OB \& Stark GR (1998) The p53 network. Journal of Biological Chemistry 273, $1-4$.
An WG, Kanekal M, Simon MC, Maltepe E, Blagosklonny MV \& Neckers LM (1998) Stabilization of wild-type p53 by hypoxiainducible factor 1 alpha. Nature 392, 405-408.

Calmels S, Hainaut P \& Ohshima H (1997) Nitric oxide induces conformational and functional modifications of wild-type p53 tumor suppressor protein. Cancer Research 57, 3365-3369.

Cho Y, Gorina S, Jeffrey PD \& Pavletich NP (1994) Crystal structure of a p53 tumor suppressor-DNA complex: understanding tumorigenic mutations. Science 265, 346-355.

Fong LY, Lau KM, Huebner K \& Magee PN (1997) Induction of esophageal tumors in zinc-deficient rats by single low doses of N-nitrosomethylbenzylamine (NMBA): analysis of cell proliferation, and mutations in H-ras and p53 genes. Carcinogenesis 18, 1477-1484.

Funk WD, Pak DT, Karas RH, Wright WE \& Shay JW (1992) A transcriptionally active DNA-binding site for human p53 protein complexes. Molecular and Cellular Biology 12, 2866-2871.

Graeber TG, Osmanian C, Jacks T, Housman DE, Koch CJ, Lowe SW \& Giaccia AJ (1996) Hypoxia-mediated selection of cells with diminished apoptotic potential in solid tumours. Nature 379, 88-91.

Greenblatt MS, Bennett WP, Hollstein M \& Harris CC (1994) Mutations in the p53 tumor suppressor gene: clues to cancer etiology and molecular pathogenesis. Cancer Research 54, 4855-4878.

Gu W \& Roeder RG (1997) Activation of p53 sequence-specific DNA binding by acetylation of the p53 C-terminal domain. Cell 90, 595-606.

Hainaut P, Hernandez T, Robinson A, Rodriguez-Tome P, Flores T, Hollstein M, Harris CC \& Montesano R (1998) IARC Database of p53 gene mutations in human tumors and cell lines: updated compilation, revised formats and new visualisation tools. Nucleic Acids Research 26, 205-213.

Hainaut P \& Hollstein M (1999) p53 and human cancer: the first ten thousand mutations. Advances in Cancer Research 77, 81-137.

Hainaut P \& Milner J (1993a) A structural role for metal ions in the 'wild-type' conformation of the tumor suppressor protein p53. Cancer Research 53, 1739-1742.

Hainaut P \& Milner J (1993b) Redox modulation of p53 conformation and sequence-specific DNA binding in vitro. Cancer Research 53, 4469-4473.

Hainaut P, Rolley N, Davies M \& Milner J (1995) Modulation by copper of p53 conformation and sequence-specific DNA binding: role for $\mathrm{Cu}(\mathrm{II}) / \mathrm{Cu}(\mathrm{I})$ redox mechanism. Oncogene 10 , 27-32.

Haupt Y, Maya R, Kazaz A \& Oren M (1997) Mdm2 promotes the rapid degradation of p53. Nature 387, 296-299.

Hernandez TM \& Hainaut P (1998) Tumor-specific mutation spectra in the human p53 gene: from carcinogen 'fingerprints' to functional consequences. Environmental Carcinogenesis and Ecotoxicology Reviews C 16, 31-45.

International Agency for Cancer Research (1993) IARC Monographs on the Evaluation of Carcinogenic Risks no. 58. Beryllium, Cadmium, Mercury and Exposures in the Glass Manufacturing Industry. Lyon: IARC.

Jayaraman L, Murthy KG, Zhu C, Curran T, Xanthoudakis S \& Prives C (1997) Identification of redox/repair protein Ref-1 as a potent activator of p53. Genes and Development 11, 558-570.

Knudson AGJ (1971) Mutation and cancer: statistical study of retinoblastoma. Proceedings of the National Academy of Sciences USA 68, 820-823.

Kubbutat MH, Jones SN \& Vousden KH (1997) Regulation of p53 stability by Mdm2. Nature 387, 299-303.

Lane DP (1992) Cancer. p53, guardian of the genome. Nature $\mathbf{3 5 8}$, $15-16$. 
Levine AJ (1997) p53, the cellular gatekeeper for growth and division. Cell 88, 323-331.

Oliner JD, Pietenpol JA, Thiagalingam S, Gyuris J, Kinzler KW \& Vogelstein B (1993) Oncoprotein MDM2 conceals the activation domain of tumour suppressor p53. Nature 362, 857-860.

Polyak K, Xia Y, Zweier JL, Kinzler KW \& Vogelstein B (1997) A model for p53-induced apoptosis. Nature 389, 300-305.

Shieh SY, Ikeda M, Taya Y \& Prives C (1997) DNA damageinduced phosphorylation of p53 alleviates inhibition by MDM2. Cell 91, 325-334.

Siliciano JD, Canman CE, Taya Y, Sakaguchi K, Appella E \& Kastan MB (1997) DNA damage induces phosphorylation of the amino terminus of p53. Genes and Development 11, 3471-3481.

Vallee BL (1991) Introduction to metallothionein. Methods in Enzymology 205, 3-7.

Verhaegh GW, Parat MO, Richard MJ \& Hainaut P (1998) Modulation of p53 protein conformation and DNA-binding activity by intracellular chelation of zinc. Molecular Carcinogenesis 21, 205-214.
Verhaegh GW, Richard MJ \& Hainaut P (1997) Regulation of p53 by metal ions and by antioxidants: dithiocarbamate downregulates p53 DNA-binding activity by increasing the intracellular level of copper. Molecular and Cellular Biology 17, 5699-5706.

Wahrendorf J, Munoz N, Lu JB, Thurnham DI, Crespi M \& Bosch FX (1988) Blood, retinol and zinc riboflavin status in relation to precancerous lesions of the esophagus: findings from a vitamin intervention trial in the People's Republic of China. Cancer Research 48, 2280-2283.

Waterman MJ, Stavridi ES, Waterman JL \& Halazonetis TD (1998) ATM-dependent activation of p53 involves dephosphorylation and association with 14-3-3 proteins. Nature Genetics 19, $175-178$.

Woo RA, McLure KG, Lees-Miller SP, Rancourt DE \& Lee PW (1998) DNA-dependent protein kinase acts upstream of p53 in response to DNA damage Nature 394, 700-704.

Wu J, Forbes JR, Chen HS \& Cox DW (1994) The LEC rat has a deletion in the copper transporting ATPase gene homologous to the Wilson disease gene. Nature Genetics 7, 541-545. 
